\title{
PERANAN JAKSA PENGACARA NEGARA DALAM MENYELESAIKAN KASUS MEWAKILI BADAN PENYELENGGARA JAMINAN SOSIAL (BPJS) KETENAGAKERJAAN DI DENPASAR
}

\author{
Gusti Ayu Ajeng Prabaningtyas, I Nyoman Putu Budiartha, I Made Minggu Widyantara \\ Fakultas Hukum, Universitas Warmadewa, Denpasar-Bali, Indonesia \\ aajengprabaningtyas@gmail.com, budiarthaputu59@gmail.com, mademinggu21@gmail.com
}

\begin{abstract}
Abstrak
Jaksa sebagai penerima kuasa dalam surat kuasa khusus, yang dalam hal ini mewakili BPJS Ketenagakerjaan, menangani persoalan hukum terkait para pengusaha yang belum mencatat dirinya dan staf menjadi anggota Program Tanggungan Tenaga Kerja. Tujuan penelitian ini untuk mengungkap peran jaksa pengacara negara dalam menyelesaikan kasus mewakili Badan Penyelenggara Jaminan Sosial (BPJS) ketenagakerjaan di Denpasar serta upaya jaksa pengacara negara dalam menyelesaikan kasus mewakili BPJS ketenagakerjaan di Denpasar. Tipe penelitian ini berupa sosiologis dengan pendekatan yuridis empiris. Teknik pengumpulan data dilakukan dengan studi kepustakaan, pengamatan, wawancara yang berkaitan dengan penelitian ini. Sumber data yang digunakan berupa data sekunder dan primer yang kemudian dianalisis secara sistematis. Hasil penelitian menunjukkan bahwa peran Jaksa Pengacara Negara dalam menyelesaikan kasus mewakili BPJS Ketenagakerjaan sebagai kuasa hukum dengan Kuasa Khusus untuk menyelesaikan terkait perusahaan belum mendata dirinya dan stafnya dalam Program Tanggungan Tenaga Kerja. Adapun upaya Pengacara Negara dalam menyelesaikan kasus mewakili BPJS Ketenagakerjaan, dengan Surat Kuas a Khusus dari BPJS Ketenagakerjaan Jaksa Pengacara Negara bertindak dalam hal melakukan bantuan hukum non litigasi dengan melakukan mediasi terhadap badan usaha maupun perseorangan yang tidak mendaftar sebagai anggota Badan Jaminan Sosial Ketenagakerjaan ataupun belum patuh melunasi retribusi.
\end{abstract}

Kata Kunci: BPJS, Jaksa Pengacara Negara, Kasus

\begin{abstract}
The prosecutor as the recipient of the power of attorney in a special power of attorney, which in this case represents employment BPJS, handles legal issues related to entrepreneurs who have not registered themselves and staff as members of the Manpower Dependent Program. The purposes of this study are to reveal the role of state attorneys in resolving cases representing the Social Security Administering Body (BPJS) for employment in Denpasar and the efforts of state attorneys to resolve cases representing BPJS for employment in Denpasar. This type of research is sociological with an empirical juridical approach. Data collection techniques were carried out by literature study, observation, interviews related to this research. Sources of data used in the form of secondary and primary data which are then analyzed systematically. The results of the study indicate that the role of the State Attorney's Attorney in resolving cases representing BPJS Ketenagakerjaan as a legal counsel with a Special Power of Attorney to resolve the company has not recorded itselfand its staff in the Manpower Dependent Program. While the efforts of State Lawyers in resolving cases representing BPJS Ketenagakerjaan, with a Special Power of Attorney from BPJS Ketenagakerjaan, State Atto rneys act in terms of providing nonlitigation legal assistance by mediating business entities and individuals who do not register as members of the Employment Social Security Agency or have not complied with the payment of fees.
\end{abstract}

Keywords: BPJS, State Attorney, Case

\section{PENDAHULUAN}

Negara untuk melindungi masyarakatnya untuk mendapatkan kesejahteraannya yang dijamin oleh hukum. Banyaknya karyawan, sekitar hampir 100 juta orang dan tentu akan semakin meningkat dari 2 (dua) persen per tahun (Husni, 2003). Tanggungan para pekerja yang tercipta demi mendapatkan dan menyusun pertahanan kepada pekerja dari tampaknya kejadian materi yang mengakibatkan hilangnya sebagian atau seluruhnya penghasilan pekerja disebabkan oleh hal-hal diluar kemampuannya (Khairani, 2016). Perlindungan Pekerja dalam bidang Jaminan Sosial, dalam bentuk badan hukum yang bertugas untuk melakukan penyelenggaraan program jaminan sosial untuk melindungi hak-hak 
masyarakat termasuk pekerja yakni dibentuknya Badan Jaminan Sosial Tenaga Kerja. Dengan adanya jaminan ini tiap-tiap karyawan mampu mencukupi keperluan pokok hidup yang memadai apabila timbul situasi yang menimbulkan putus/menurunnya penghasilan disebabkan sakit, menghadapi musibah, kehilangan pekerjaan, melalui lanjut umur atau pensiun.

Dari amanat Undang-undang yang telah ada untuk memberikan perlindungan terhadap pekerja khususnya dalam mendapatkan Jaminan Sosial, namun pada implementasi di lapangan masih banyak ditemukan para pekerja belum mendapatkan Jaminan Sosial seperti yang telah dipersyaratkan Undang-undang tersebut. Zaman sekarang ini banyak pekerjaan yang memiliki tingkat resiko yang tinggi. Dimana resiko tersebut bisa seperti kehilangan nyawa, luka ringan, luka berat ataupun sampai cacat seumur hidup.BPJS Ketenagakerjaan dalam kondisi tersebut merupakan Lembaga jaminan sosial yang dapat menjadi tenaga kerja apabila mengalami kecelakaan pada saat melaksanakan tugasnya di jam kerja.

Semakin lama dilihat kurangnya perhatian perusahaan kepada para pekerjanya.Dilihat dari berbagai macam kasus yang telah terjadi.Mulai dari kasus permasalahan pendaftaran Perusahaan Wajib Belum Daftar (PWBD) pada BPJS Ketenagakerjaan terhadap para pekerjanya.Dengan adanya hal tersebut maka banyak para pekerja yang dirugikan mengenai tanggungan bagi karyawan dan keluarganya sepatutnya mencukupi keperluan pokok hidup pada saat terjadi risiko dapat memberikan dampak hilangnya pendapatan.

Dalam penelitian ini akan dibahas mengenai pemberi kerja wajib mendaftarkan dirinya dan pekerjanya sebagai peserta Program Jaminan Sosial kepada BPJS Ketenagakerjaan. Pengusaha atau badan hukum yang mempekerjakan pegawai dan memberikan bayaran, honorarium, atau komisi dalam bentuknya lainnya, sehingga dalam hal ini penulis melihat Lembaga Pemerintahan yang berperan dalam rangka optimalisasi program jaminan sosial bagi pekerja tersebut, yaitu

1. Badan Penyelenggara Jaminan

Badan hukum publik yang bertugas melindungi seluruh pekerja baik dalam sosial maupun kesehatan.

2. Perusahaan

Pengusaha yang memberikan gaji ataupun upah, tunjangan dan honorarium sebagai imbalan sehubungan dengan pekerjaan, jasa atau kegiatan yang dilakukan oleh pegawai.

3. Kejaksaan Republik Indonesia

Lembaga pemerintah yang diberi tugas dan wewenang dalam hal penuntut dan penyidikan. Badan Jaminan Ketenagakerjaan saat menjalankan programnya yang selalu berupaya mengajak para Pemberi Kerja untuk dapat mengikutsertakan stafnya menjadi anggota untuk tanggungan tenaga kerja, namun dalam pelaksanaannya ditemui hambatan- hambatan sebagai berikut

1. Adanya ditemui dilapangan para pemberi kerja kadang tidak sepenuhnya melindungi Pekerjanya dengan mengikutsertakan para Pekerjanya secara keseluruhan, namun hanya mengikutsertakan sebagian Pekerjanya saja, dengan alasan bahwa jika diikutsertakan seluruh Pekerja akan memberatkan beban perusahaan.

2. Ditemui keadaan adanya Pekerja yang tidak tetap yang bekerja di perusahaan pemberi kerja, bias dikatakan para Pekerja bekerja jika ada pekerjaan saja, dan jika pekerjaan telah selesai maka Pekerja tidak bekerja di perusahaan tersebut, dan akan dipanggil lagi jika perusahaan mendapatkan paket pekerjaan kembali, sehingga perusahaan menemui kesulitan dalam hal melakukan pendataan terhadap pekerja yang bekerja insidentil tersebut, dan banyak perusahaan lebih memilih tidak mengikutsertakan pekerja dalam rancangan jaminan sosial.

Menyikapi temuan-temuan yang sering terjadi, BPJS khususnya BPJS Ketenagakerjaan baru hanya sebatas mengajak dan memberi peringatan kepada pemberi kerja agar dapat mengikutsertakan pekerjanya kedalam program jaminan sosial yang kadang kalanya tidak dipatuhi sepenuhnya oleh pemberi kerja walaupun dalam amanat Undang-undang, pemberi kerja dapat dikenakan sanksi. Kerjasama dengan Kejaksaan Republik Indonesia dalam hal ini Kejaksaan Negeri Denpasar baru dalam sebatas kerjasama dalam sosialisasi untuk menambah pemahaman Pemberi Kerja dalam melindungi pekerjanya melalui keikutsertaan dalam program Jaminan Sosial yaitu BPJS. Badan Penyelenggara Jaminan Sosial atau BPJS merupakan lembaga yang dibentuk untuk menyelenggarakan program jaminan sosial di Indonesia menurut Undang-undang Nomor 40 Tahun 
2004 dan Undang-undang Nomor 24 Tahun 2011 yang terdiri dari BPJS Kesehatan dan BPJS Ketenagakerjaan (Widada, 2017); (Widiastuti, 2017).

Kerjasama termasuk dalam melakukan pemanggilan terhadap perusahaan yang belum mendaftarkan para pegawainya menjadi peserta BPJS Ketenagakerjaan dan penagihan-penagihan terhadap tunggakan-tunggakan yang dilakukan oleh para pemberi kerja. Jaksa yang dalam hal ini sebagai penerima kuasa yang mewakili BPJS Ketenagakerjaan dapat melakukan pemanggilan kepada perusahaan dan juga karyawannya dalam rangka melakukan mediasi mengenai belum terdaftarnya dalam program BPJS Ketenagakerjaan, Jaksa sebagai kuasa hukum memberikan batas waktu untuk melakukan pendaftaran dan mendata pekerjanya untuk ikut serta sebagai anggota program jaminan sosial ketenagakerjaan agar hak-hak jaminan sosial sebagai tenaga kerja tetap terlindungi dan harus menjadi perhatian kita bersama.

Selain dalam peradilan pidana, pada dasarnya kejaksaan juga memiliki peran di bidang hukum, perdata dan tata usaha negara, yaitu mewakili negara dan pemerintah dalam perkara perdata dan tata usaha negara (TUN) sesuai Pasal 30 ayat (2) UU Kejaksaan (Putra et al., 2017). Sebagai pengacara negara dalam bidang perdata, kejaksaan dapat bertindak di dalam maupun diluar pengadilan untuk dan atas nama negara atau pemerintahan (Rusdianto, 2015). Adapun menurut Simanjuntak (2018) fungsi kejaksaan dalam peradilan perdata yaitu menjamin tegaknya hukum, menjaga kewibawaan pemerintah, dan melindungi kepentingan masyarakat. Jaksa Pengacara Negara adalah Jaksa dengan Kuasa Khusus, bertindak untuk dan atas nama Negara atau Pemerintah dalam melaksanakan tugas dan wewenang Kejaksaan dibidang perkara Perdata dan Tata Usaha Negara. Dari beberapa temuan penelitian terdahulu, maka penelitian saat ini mengkaji peran jaksa pengacara negara dalam menyelesaikan kasus mewakili Badan Penyelenggara Jaminan Sosial (BPJS) ketenagakerjaan di Denpasar serta upaya jaksa pengacara negara dalam menyelesaikan kasus mewakili BPJS ketenagakerjaan di Denpasar.

\section{METODE PENELITIAN}

Metode dalam hal ini menggunakan suatu cara atau langkah yang dipergunakan oleh peneliti dalam menggabungkan petunjuk penelitiannya (Arikunto, 2000). Penelitian empiris/sosiologis suatu metode penelitian hukum dengan mengamati kejadian yang sering terjadi di dalam masyarakat. Pendekatan yuridis empiris adalah penelitian yang mengkaji mengenai kejadian mengerjakan pedoman bagaimana menautkan data-data yang ada sesuai dengan penelitian dan bagaimana pada kondisi perusahaan (Soemitro, 2001). Pendekatan hukum Empiris, didapat dari pelaksanaan tanggungan bagi para karyawan yang belum diikutsertakan menjadi anggota BPJS Ketenagakerjaan oleh pemberi kerja. Secara yuridis peranan Jaksa Pengacara Negara menyelesaikan masalah mewakili BPJS Ketenagakerjaan di Denpasar dikaitkan dengan Pasal 30 ayat (2) tentang Kejaksaan Republik Indonesia, dan juga pada tentang Jaminan Sosial Tenaga Kerja. Teknik pengumpulan data dilakukan dengan studi kepustakaan, pengamatan, wawancara yang berkaitan dengan penelitian ini. Sumber bahan hukum yang digunakan adalah bahan hukum primer yang didapat dengan menganalisis peraturan perundang-undangan, risalah resmi, dan beberapa keputusan-keputusan yang menyangkut dengan judul penelitian ini. Bahan hukum sekunder didapat dari menganalisis bukubuku, jurnal-jumal dan hasil-hasil penelitian terdahulu yang memiliki keterkaitan dengan judul penulisan ini yang kemudian dianalisis dengan deskriptif.

\section{HASIL DAN PEMBAHASAN}

\section{Peran Jaksa Pengacara Negara dalam Menyelesaikan Kasus Mewakili Badan Penyelenggara Jaminan Sosial (BPJS) Ketenagakerjaan di Denpasar}

Lembaga Kejaksaan merupakan perakat pemerintah yang berfungsi sebagai penuntut umum saja yang menjadi kewajiban utamanya, namun juga dalam perkara perdata, dimana Jaksa Pengacara Negara dalam kedudukannya selaku kuasa hukum pemerintah Jaksa sebagai Pengacara Negara belum begitu akrab dalam masyarakat sekitar, karena lebih sering dengan sebutan Kejaksaan sama dengan institusi pemerintah yang berkedudukan jaksa penuntut umum dalam hal mengurus perkara pidana maupun perdata. Peraturan mengenai Kejaksaan tidak ada kejelasan mengenai pengertian tentang Jaksa Pengacara Negara. Menurut hukum, Jaksa Pengacara Negara secara tegas dijelaskan mempunyai peran dalam upaya penumpasan tindak pidana korupsi yang ketegasannya pada kapasitas Jaksa sebagai Pengacara Negara yaitu penegakan hukum. 
Jaksa Pengacara Negara atau jaksa pengacara negara mempunyai kapasitas sama dengan seperti tokoh yang berperan untuk menunjang hak-hak negara dalam menyita dana atau aset yang dapat merugikan negara. Kewajiban dan otoritas kejaksaan dalam bekerja sebagaimana Jaksa Pengacara Negara. Kataran sebagai Jaksa mempunyai tatanan hukum menurut Undang-undang Kejaksaan Republik Indonesia. Persoalaan dapat berkecambah tatkala jaksa sebagai penerima kuasa menangani suatu perkara perdata, legal atau tidak untuk menggantikan mayoritas harapan kelompok rakyat dan negeri, yang berhubungan mengenai otoritas Kejaksaan menangani kasus Menurut Kejaksaan RI menyebutkan mengenai aturan-aturan serta mengukuhkan beberapa peranan dan wewenang Jaksa Pengacara Negara, ketika negara merupakan ada pada sisi dalam mempersoalkan dalam bidang perdata dan pengujian mengenai perbuatan tata laksana terhadap dirinya yang dilakukan oleh hakim pengadilan tata usaha negara sesuai dengan peraturan yang berlaku secara hukum (Surachman \& Hamzah, 1996).

Ketika hubungannya melalui kekuasaan jaksa sebagai pengacara negara dalam mewujudkan harapan pada hukum, cara di luar pengadilan maupun di pengadilan berbentuk usulan tuntutan ke pengadilan, Badan Jaminan Tenaga Kerja sebagai BUMN memilih Jaksa Pengacara Negara sebagai Pengacara. Awal pemilihan Jaksa yang dipilih sebagai Pengacara di perkara mengenai belum tercatatnya perusahaan maupun stafnya sebagai anggota dari BPJS Ketenagakerjaan. Mengenai tentang isi perjanjian kerjasama (MOU) yang dijalin pada tanggal 6 Mei 2020, Bapak Mohamad Irfan selaku Kepala BPJS Ketenagakerjaan Cabang Bali Denpasar menggandeng Kejaksaan Negeri Denpasar untuk menyelesaikan kasus hukum terkait badan hukum/perusahaan yang belum mengikutsertakan perusahaannya begitu pula para pegawainya menjadi anggota BPJS Ketenagakerjaan. Mengenai kolaborasi antara BPJS Ketenagakerjaan dan Kejaksa an berisi berke naan penetapan Jaksa Pengacara Negara sebagai Kuasa Hukum. BPJS menyebutkan tentang keharusan badan hukum mengharuskan mendata baik perusahaan maupun stafnya menjadi anggota pada Tanggungan Tenaga Kerja, perusahaan patutnya menyampaikan identitas data perusahaan tersebut dan para pegawainya serta seluruh secara komplit dan sesuai.

\section{Upaya Jaksa Pengacara Negara dalam Menyelesaikan Kasus Mewakili BPJS Ketenagakerjaan di Denpasar}

Jaksa Pengacara Negara, memiliki pengertian yang berbeda di setiap kata-katanya yaitu

1. Jaksa sebagai perangkat pemerintah pada bidang hukum yang berkewajiban memberikan tuduhan/gugatan pada jalannya sidang pengadilan terhadap orang yang diduga telah melanggar hukum.

2. Pengacara, merupakan profesi yang menawarkan jasa hukum di dalam maupun di luar pengadilan.

3. Negara, kelompok pengaruh yang berkuasa dengan aturan pemerintahan yang melakukan disiplin atas orang-orang di daerah tertentu.

Jaksa Pengacara Negara sebagai Jaksa bertindak dengan kuasa khusus, bekerja bertindak mewakili negeri menangani persoalan. Sementara itu jaksa merupakan PNS sebagai penuntut umum kepada orang yang melanggar di muka persidangan dan mewujudkan pidana mendapatkan kewenangan menurut Undang-undang (Marbun, 2004).

Jaksa Pengacara Negara sebagai lembaga penegak hukum dalam lingkungan pemerintah eksekutif yang paling penting, Kejaksaan dalam mengemban tugas dan wewenangnya diharapkan memiliki jati diri yang profesional sebagai wakil negara dalam penegakan hukum. Pada terwujudnya sistematis dan prosedur sistem pada bidang sebagaimana dikerjakan oleh Kejaksaan Negeri Denpasar, dengan tujuan agar dapat memperkenalkan pemberian layanan hukum kepada BPJS Ketenagakerjaan. Dalam Perjanjian Nota Kesepahaman tercantum mengenai BPJS Ketenagakerjaan yang menelaah menerima konsisten dari semua Kepala Bagian Ketenagakerjaan, memberikan pemahaman mengenai kejaksaan sebagai Jaksa Pengacara Negara yang akan memperingatkan badan hukum/perusahaan yang belum mencatat baik karyawannya maupun upahnya (Ibu Annisa, di Kejaksaan Negeri Denpasar).

Perjanjian Nota Kesepahaman antara kedua belah pihak yang memiliki visi dan misi serupa yaitu menambah besaran keanggotaan dalam Program Jaminan Sosial Tenaga Kerja. Maksud terjalinnya kerjasama ini dan seperti apa yang sudah tercantum mengenai sepakat lebih menumbuhkan daya guna pengendalian urusan hukum. Kerja sama antara Badan Penyelenggara Jaminan Sosial 
Ketenagakerjaan dan Kejaksaan Negeri mengenai kuasa khusus dalam menangani penyelesaian permasalahan yang terjadi apabila badan hokum tidak ikut serta dalam mendaftarkan stafnya sebagai bentuk tanggungan untuk tenaga kerja yang tercantum menurut Jaminan Sosial pada program BPJS Ketenagakerjaan.

Kesepakatan Perjanjian Nota Kesepahaman dalam memberikan kuasa khusus untuk melakukan mediasi atau pemanggilan kepada Pengusaha dan para pekerjanya yang belum melakukan kewajibannya untuk mengikutsertakan atau mendaftar pada BPJS Ketenagakerjaan dan memberikan sosialisasi menjelaskan bahwa BPJS Ketenagakerjaan wajib guna memberikan perlindungan kepada para pekerjanya apabila terjadi kecelakaan saat bekerja (Bapak Bagus, di Kejaksaan Negeri Denpasar). Perjanjian Kesepahaman dalam memberikan layanan hukum untuk mewakili BPJS Ketenagakerjaan yang dalam hal ini jaksa sebagai pengacara negara melalui surat kuasa khusus membantu menyelesaikan masalah pemanggilan kepada perusahaan/badan hukum yang tidak mengikutsertakan para stafnya sebagai anggota dalam jaminan sosial tenaga kerja (Bpk. Bagus, di Kejaksaan Negeri Denpasar).

Perjanjian Kerjasama Nota Kesepakatan bersama yang telah disepakati antara BPJS Ketenagakerjaan dan Kejaksaan Negeri isinya menerangkan perjanjian yang tertera pada kesepakatan yang mengikat antara hak dan kewajiban. Mengenai terjalinnya perjanjian kerjasama nota kesepahaman ini adalah untuk dapat mempermudah kebijakan dan kesepakatan antara sejumlah kelompok institut untuk menerapkan jaminan sosial BPJS Ketenagakerjaan sesuai pada program BPJS Ketenagakerjaan kepada masyarakat dengan cara menggabungkan biaya.

Kejaksaan Negeri dalam menyelesaikan permasalahan perusahaan yang belum mendaftarkan karyawannya, sebelumnya telah mendapatkan surat kuasa khusus dari BPJS Ketenagakerjaan dalam menggunakan haknya sebagai penerima kuasa untuk mendampingi pemberi kuasa mengambil segala tindakan, keputusan, membuat, menandatangani, mengajukan dan menerima surat-surat termasuk menandatangani berita acara keberhasilan/atau kegagalan mediasi dan memberikan keteranganketerangan yang menurut hukum harus dijalankan dan/atau diberikan oleh seorang penerima kuasa. Pemanggilan yang dilakukan tim jaksa sebagai mediator dilakukan melalui pendekatan persuasif. Pemanggilan secara resmi Pengusaha selaku pemberi kerja agar dapat hadir pada kantor Kejaksaan Negeri. Isi surat panggilan adalah mengundang para perusahaan/badan hukum untuk melakukan mediasi mengenai surat teguran yang telah diberikan sebelumnya oleh pihak BPJS Ketenagakerjaan dengan isi peringatan pertama untuk perusahaan/badan hukum yang tidak mendata perusahaan dan para stafnya sebagai anggota pada BPJS Ketenagakerjaan. Para Perusahaan yang mengabaikan dan belum mendaftarkan para pekerjanya sebagai peserta jaminan sosial akan dievaluasi oleh pihak Kejaksaan Negeri untuk mensinergikan implementasi kewajiban perusahaan dalam kepesertaan jaminan sosial guna perlindungan dan kenyamanan kepada karyawannya sehingga dapat lebih memfokuskan pada peningkatan tekad ataupun kreatifitas pekerjanya.

\section{SIMPULAN DAN SARAN}

\section{Simpulan}

Berdasarkan dalam pembahasan sebelumnya, maka dapat disimpulkan mengenai beberapa pokok, yaitu peran Jaksa Pengacara Negara dalam menyelesaikan kasus mewakili BPJS Ketenagakerjaan sebagai penerima kuasa dalam surat kuasa hukum dalam Kuasa digunakan dalam menyelesaikan kasus hukum terkait perusahaan yang belum mengikutsertakan dirinya dan para karyawannya sebagai anggota Program BPJS Ketenagakerjaan. Keharusan untuk mengikutsertakan para karyawannya ikut dalam peserta Tujuan dari BPJS Ketenagakerjaan, dengan tujuan guna ketenteraman para karyawannya sebagai pekerja pada perusahaan untuk lebih mendapatkan keselamatan selama bekerja di jam kerja. Andaikata perusahaan tidak menuruti peraturan yang terkandung, maka dijatuhi denda sesau dengan peraturan yang berlaku. Adapun upaya Jaksa Pengacara Negara dalam menyelesaikan kasus mewakili BPJS Ketenagakerjaan di Denpasar, Pada segi Datun dalam Kuasa Khusus dari BPJS Ketenagakerjaan Jaksa Pengacara Negara yang mewakili BPJS Ketenagakerjaan dalam hal melakukan bantuan hukum di luar pengadilan dengan melakukan mediasi terhadap pemberi kerja yang tidak mendata menjadi anggota BPJS Ketenagakerjaan tercantum dalam Undang-undang Nomor 40 Tahun 2004 tentang sistem jaminan sosial nasional serta Undang-Undang Nomor 24 Tahun 2011 tentang Badan Penyelenggara Jaminan Sosial ataupun tidak patuh membayar iuran. 


\section{Saran}

Diharapkan BPJS Ketenagakerjaan melakukan sosialisasi secara berkesinambungan dan berkala kepada Pemberi Kerja dan pekerjanya mengenai program jaminan sosial yang memberikan keselamatan dalam setiap melakukan pekerjaan di jam kerja karyawan tersebut serta anggota keluarganya agar dapat melengkapi keperluan hidup yang memadai pada saat terjadi masalah yang mengakibatkan menurunnya atau tidak adanya pendapatan. Hendaknya peraturan lebih meyakinkan mengenai perundang-undangan dengan pokok utama lebih sesuai mengenai kewajiban dan wewenang dari penerima kuasa (jaksa) menjadi pengacara mewakili negara menyelesaikan masalah yang khususnya menyangkut batasan wewenang Jaksa Pengacara Negara mengenai permasalahan non litigasi lantara tercantum dalam Undang-undang Kejaksaan pun tiada ketegasan aturan pokok mengatur fokus pada uraian secara tegas mengenai wewenang yang harus dipatuhi dan dimiliki oleh jaksa sebagai pengacara negara.

\section{DAFTAR PUSTAKA}

Arikunto, S. (2000). Prosedur Penelitian Suatu Pendekatan Praktek. Rineka Cipta, Yogyakarta. Husni, L. (2003). Pengantar Hukum Ketenagakerjaan Indonesia. Raja Grafindo Persada, Jakarta. Khairani. (2016). Kepastian Hukum Hak Pekerja Outsourcing. Raja Grafindo Persada, Jakarta.

Marbun, B. N. (2004). Kamus Hukum Indonesia. Raja Grafindo Persada, Jakarta.

Putra, A. K., Rani, F. A., \& Syahbandir, M. (2017). Eksistensi Lembaga Kejaksaan Sebagai Pengacara Negara dalam Penegakan Hukum di Bidang Perdata dan Tata Usaha Negara (Suatu Penelitian Pada Kejaksaan Tinggi Aceh). Syiah Kuala Law Journal, 1(2), 163-182.

Rusdianto. (2015). Fungsi Kejaksaan Sebagai Pengacara Negara dalam Perspektif Penegakan Hukum di Indonesia. Jurnal Cakrawala Hukum, 6(1),99-108.

Simanjuntak, J. (2018). Kajian Yuridis Pemberian Bantuan Hukum Jaksa Pengacara Negara dalam Perkara Perdata dan Tata Usaha Negara (TUN). Lex Administratum, 6(1), 152-163.

Soemitro, R. H. (2001). Metodologi Penelitian Hukum dan Jurimetri. Ghalia Indonesia, Jakarta.

Surachman, R., \& Hamzah, A. (1996). Jaksa diberbagai Negara dan Kedudukannya. Sinar Harapan, Jakarta. Jaksa diberbagai Negara dan Kedudukannya

Widada, T. (2017). Peran Badan Penyelenggara Jaminan Sosial (BPJS) Kesehatan dan Implikasinya Terhadap Ketahanan Masyarakat (Studi di RSUD Hasanuddin Damrah Manna, Kabupaten Bengkulu Selatan, Provinsi Bengkulu). Jurnal Ketahanan Nasional, 23(2), 199-216.

Widiastuti, I. (2017). Pelayanan Badan Penyelenggara Jaminan Sosial (BPJS) Kesehatan di Jawa Barat. Jurnal Administrasi Publik, 2(2), 91-101. 